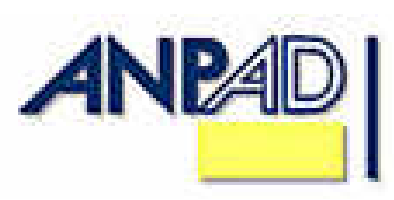

Available online at

http://www.anpad.org.br/bar

\title{
Organizational Culture and the Renewal of Competences
}

\author{
Maria Tereza Leme Fleury * \\ E-mail address: mtfleury@usp.br \\ Faculdade de Economia, Administração e Contabilidade da Universidade de São Paulo - FEA/USP \\ São Paulo, SP, Brazil.
}

\begin{abstract}
Culture and competence are fairly well-known topics; both are part of the academic agenda and are widely discussed in day-to-day debates within organizations. However, the interactions between these two concepts and their interdependence are yet to be analyzed. Those are areas of organizational phenomena that might be complementary or even be contradictory. The aim of this paper is to discuss the relationship between these two subjects. Does organizational culture enhance or jeopardize the development of new competences? Is it possible for an organization to develop new competences while keeping its core values? This paper proposes an initial incursion into this debate, revisiting the concept of culture and cross checking it with the concept of competence; two case studies of Brazilian firms are presented in order to illustrate this debate.
\end{abstract}

Key words: culture; organizational competence.

Received 29 November 2007; received in revised form 08 October 2008.

Copyright (C) 2009 Brazilian Administration Review. All rights reserved, including rights for translation. Parts of this work may be quoted without prior knowledge on the condition that the source is identified.

* Corresponding author: Maria Tereza Leme Fleury

Av. Prof. Luciano Gualberto, 908, sala E-118, Cidade Universitária, São Paulo, SP, 05508-900, Brazil. 


\section{INTRODUCTION}

Culture and competence are fairly well-known topics; both are part of the academic agenda and are widely discussed in day-to-day debates within organizations. However, the interactions between these two concepts and their interdependence are yet to be analyzed. These are areas of organizational phenomena that might be complementary or even be contradictory.

The concept of culture refers to the values and meanings that influence human behavior and organizational practices, whereas competence refers to the mobilization/coordination of resources by an organization or a person.

The aim of this paper is to discuss the relationship between these two subjects. Does organizational culture enhance or jeopardize the development of new competences? Is it possible for an organization to develop new competences while keeping its core values?

This paper proposes an initial incursion into this debate, revisiting the concept of culture and cross checking it with the concept of competence. An analysis of literature on competence, seeking references on organizational culture, provides the theoretical framework of this study; two cases studies of Brazilian firms are presented in order to illustrate this debate.

\section{THE CONCEPT OF ORGANIZATIONAL CuLtuRE}

The concept of culture was introduced into management sciences in the late 60s.

The process whereby European and American companies became multinationals, expanding their operations to other continents, led them to reproduce their management practices in order to gain competitive advantages in countries other than their own through cheap labor, new markets or proximity to raw materials, among other elements. However, although they sought to reproduce the practices as closely as possible, the outcomes were rarely compatible. In general, managers faced problems they did not have to deal with in the multinational's home country. That is why the first notions of culture used by management were similar to those employed to define national culture.

The development of the concept of organizational culture was quite polemic, contrary to what occurred with other theoretical constructs, such as organizational climate, for example (Reichers \& Schneider, 1990). Surveying the studies on organizational culture, Reichers and Schneider show that the concept of organizational culture is borrowed from basic social sciences - mainly anthropology and sociology, as well as from psychology - unlike the concept of organizational climate, which is the product of research conducted into organizational psychology. Since they are a construct embedded in the theoretical field that employs them, the use of climate and organizational environment is more easily accepted by academics.

Therefore, as culture was a concept alien to management theory, its development gave rise to much debate among academics. Different ideas regarding the construct were developed by influential authors such as Andrew Pettigrew (1979), Linda Smirch (1983), Edgar Schein (1985).

Some issues polarized these debates: the definition of the elements that compose a company's culture and the answer to the question as to what effectively is organizational culture, i.e., whether is it something a company has or whether it is something a company is (Smirch, 1983). These are important issues for this particular study because they have an impact on the links one may establish between culture and competence. In Brazil, Freitas (1991) has developed Smirch's categories with a very interesting framework. 
On another level of analysis: national culture, Geertz Hofstede's research provided one of the key references in the field. Hofstede (1991) identified four independent dimensions of culture, which he referred to as: Distance from Power, Individualism versus Collectivism, Masculinity versus Femininity and Uncertainty Avoidance. In subsequent studies, his team developed a fifth independent dimension referred to as Confucius Dynamics, which looks at opposition between shortterm and long-term orientation and was used to partially explain the success of Asian economies in the last few decades.

In the model proposed by that author, values are represented by strong sentiments, with positive or negative extremes, such as: good and bad, normal and abnormal, dirty and clean, secure and insecure, or pretty and ugly. The values are learnt from an early age, in the first ten years of a person's life, and change very little thereafter. Practices, however, are learnt and forgotten throughout life.

In an organization, people with different values may learn similar practices; organizational culture, according to this author, is rooted in the practices learnt and shared within a person's workplace. Hofstede further recommends that in other countries companies should adopt management behaviors different from those adopted in its country of origin because management policies should conform with other spheres of people's lives in society, spheres that are beyond the organizational environment (for example, human resources management policies). Organizational studies carried out in Brazil regarding Brazilian culture have been influenced by the work of Hofstede as well as by the writings of anthropologists such as Roberto DaMatta. In his research into Brazilian management styles, Tanure (2003) studied the dimensions described by Hofstede in Latin American countries and, especially, in Brazil. Hilal (2006) applied a questionnaire instrument based on Hofstede's work for diagnosing culture in a Brazilian multinational company through the promotion of dialog between Brazilian culture and the organization's culture. In an article of a sociological nature, with theoretical roots in studies by Roberto DaMatta, Almeida (2007) carried out a survey (the Brazilian Social Survey) to characterize the Brazilian mindset. Almeida identified Brazilian cultural patterns that had already been mentioned by other authors, including authoritarianism, Brazilian shortcuts (jeitinho) and paternalism, but he noted significant differences when comparing groups with different levels of formal education. Specifically, the traits mentioned are more accentuated in groups with less formal education.

Nuances in the Brazilian cultural patterns were also found by Caldas (2006), who noted Brazilian multiple and fluid cultural profiles.

For Edgar Schein (2001), another renowned author in the field of organizational culture,

organizational culture is a set of basic assumptions that a group has devised, discovered or developed on learning how to deal with external adaptation problems and that have worked sufficiently well to be considered valid and taught to new members as the right way to perceive, think and feel vis-à-vis these problems (Schein, 2001, p. 9).

He conceives culture as a dynamic model that is learnt, transmitted and modified; he understands that the concept is broad enough to be applied in small groups, such as a work teams, or large groups, such as an organization.

Schein states that employees working at a formal and bureaucratic company may share values and basic assumptions that are much like those of an informal and horizontally-structured company. That is why studies about organizational culture should not be limited to the observation of visible artifacts, but need to include interaction with members of an organization for the understanding of their true meaning. Even explanations given by members of an organization are insufficient, as there are assumptions that are deemed to be so obvious that people and groups are not aware of them. These assumptions influence the entire interactive process of interaction between the members of a company, without them even realizing it most of the time.

These basic assumptions are not organized randomly. They are consolidated implicit cultural paradigms, with some order and consistency to guide human behavior. However, incompatible and 
inconsistent assumptions may co-exist in a single organization. Therefore, understanding the culture of an organization implies a discussion of its basic assumptions.

The importance of basic assumptions in group dynamics was actually an original theoretical production of the work of the English psychiatrist W. Bion (1975). Schein had his own particular interpretation of Bion's work, adapting his concepts to the theoretical model in which he develops the concept of organizational culture (Fleury, Shinyashiki, \& Stevenatto, 1997). A group's culture is a function of the conflict between individual desires and the group's mentality. Consequently, the group's culture will always show signs of its underlying basic assumptions (Bion, 1975).

Schein abandoned the idea of underlying standards of behavior and broadened the role of values, as well as the idea of Bion's basic assumptions, adopting Kluckhohn's proposal. Thus, members of the group may act according to principles that they consider to be so obvious and correct (profound truths) that they scarcely question them or grasp their basis or justifications.

The debate among the different lines that discuss organizational culture indicated the need to develop a conceptual proposal that, using Schein's conception as a starting point, would incorporate the political dimension inherent to such a phenomenon. In doing so, Fleury and Fischer (1989) mention that organizational culture can be conceived as a set of basic values and assumptions, expressed by symbolic elements that in their capacity to ascribe meaning and construct organizational identity, both acting as a communication and consensus element and instrumentalizing power relationships.

Brazilian studies on organizational culture were strongly influenced by authors such as Schein and Pettigrew. Most of the studies available are of a qualitative nature and focus either on one single organization or on a number of cases, and often discuss relationships between organizational culture and the Brazilian cultural environment (Prestes Motta \& Caldas, 1997). For example, Rodrigues (2006), using a historical perspective, analyzed a telecommunications company in the State of Minas Gerais, Brazil, and noted the dynamics of the cultural changes the company went through, parallel to changes in the country in general.

Aspects of power relations, as mentioned by Fleury, have also been studied, and can be included in research on organizational culture, from the perspective of Foucault (Alcadepani \& Crubellate, 2003). Borges, Borges and Borges (2008), reviewing Brazilian production from 2000 to 2004 by consulting ANPAD'S proceedings, found 82 articles that were put into five categories, according to Freitas (1991): comparative management, corporate culture, cognitive, symbolic and unconscious process.

\section{REVISITING THE CONCEPT OF ORGANIZATIONAL COMPETENCE}

The study of competence is more frequently referred to the individual level rather than to the organizational level.

Studies about organizational competences are rooted in the Resources Based View of the firm RBV perspective. Unlike other schools of thought on strategies that focus on environmental variables, RBV focuses on the company and suggests that the superior application of resources may be the main source of competitive advantages for the organization.

Understanding this perspective is fundamental in order to understand fully the concept of competences, and is not intended to replace industry analysis tools, such as Porter's analysis of the five strengths (1992), or game theory, but rather to be used as a complementary tool (Peteraf \& Barney, 2003).

The RBV approach is designed to be a way of explaining performance discrepancies of companies. The RBV approach asserts that a sustainable competitive advantage arises from the company's 
specific and scarce resources, used at a higher standard than all other competitors (Peteraf \& Barney, 2003). In other words, the difference in performance between companies is ascribed to differences in the resources they hold and the way they are applied. Resources are considered superior when they allow the company to optimize the production process and/or better satisfy consumer needs.

The RBV concept of efficiency concerns obtaining the greatest amount of benefit per unit of applied value, but, in a broader approach, it may also be seen as an organization's actual capacity to adapt to its environment. That is the interpretation of authors such as Teece, Pisano and Shuen (1997), with the concept of dynamic capability; in other words, competence should never be perceived as an inventory of resources, but as resources put into action, constantly in motion and under development Teece et al. (1997).

Therefore, RBV focuses on the resources and capabilities controlled by an organization, which support sustainable performance differentials among companies.

Prahalad and Hamel (1990) define competence as the collective learning in the organization, especially how to coordinate diverse production skills and integrate multiple streams of technologies.

A core competence is, more simply put, a source of competitive advantage, given that it is competitively unique and helps to enhance the client's perceived value or to streamline costs. However, although all core competences are sources of competitive advantages, not all competitive advantages are core competences.

Mills, Platts, Bourne and Richards (2002, p. 9) define competence as a "way of expressing how well your firm performs its required activities". The authors state that the company has strengths or a high level of competence if it is able to surpass the majority of its competitors in relation to one competitive factor that is valued by consumers. Therefore, competence becomes a variable factor and not an attribute, related to the coordination and mobilization of resources, both tangible (buildings, plants, equipment) and intangible (skills, knowledge of employers, brand).

For Mills, each competence is made up of a series of bricks called resources. Shared resources generate competences that support one another, providing support to those perceived by clients. Therefore, the advantage is developed by establishing as a pyramid of organizational competences that generate benefits valued by clients. The company's performance manifests itself as a result of the quality and management of these resources. Studies on organizational competence are recent in Brazil, having been carried out only during the last decade.

Dias, Becker, Dutra and Ruas (2008) reviewed Brazilian scientific production from 2000 to 2004 by consulting periodicals and proceedings of congresses, such as the Revista de Administração da USP [RAUSP], Revista de Administração Contemporânea [RAE/FGV], Organização e Sociedade [O\&S] and Anais do Encontro Nacional da Associação dos Cursos de Pós-graduação [ENANPAD] (chosen according to the classification criterion published by CAPES). These authors analyzed 51 articles published on the topic of competence, 12 of which deal with the question of organizational competence. Two issues appear as the most relevant: 1) strategic interaction, which deals with the question of adapting and defining the portfolio of organizational competence in regard to strategy (Fleury \& Fleury, 2004; Vasconcellos \& Cyrino, 2002) and, 2 the operational interaction between organizational competence and the functions and operations of companies. Updating this study, we identified four further articles on organizational competence that deal specifically with most of the topics mentioned above. They also bring up the issue of organizational learning.

In a recent paper, Mills (2007), analyzing the case of Toyota, Lincoln Electric, Southwest Airlines and Chaparral Steel, point out that high performance was unlikely to emerge in an organization where practices did not match the organization's values. 


\section{INTERACTION BETWEEN CULTURE AND ORGANIZATIONAL COMPETENCE}

As previously mentioned, studies about both organizational culture and organizational competences are not as commonplace as those concerning the inter-cultural competences of individuals. In a search based on the Pro Quest data base, 64 papers relating those subjects were found. These papers were classified into 3 categories: alignment of culture and competence (47 papers), intercultural competence (9 papers) and miscellaneous (11 papers). The first category discusses culture as a resource that a firm can mobilize and which has be aligned to individual competences; the second one describes competences in different cultural environments; the third category includes a variety of studies which do not present a clear view of the relationship. ProQuest is a database that indexes approximately $2,000,000$ articles and theses in all areas of knowledge. This base is updated with the addition of 55,000 new references each year. The system operates in a web environment that allows access to texts through search targets, keywords and categories classified by the system. This research was enlarged to include Brazilian national bases of periodicals and proceedings of congresses, as mentioned above.

The categories were established by analyzing the contents of the articles listed. Two categories were originally defined. Later, a third category was added, covering articles that did not fit into either of the first two. Articles were also classified according to the methodology employed, but this point will not be discussed here, as it goes beyond the scope of this article. The categories were established on the basis of the theoretical frameworks mentioned in Item 3, especially in the texts by Smirch, Schein and Hofstede. Three evaluators were called in, and followed a methodological approach employed by other authors (Fleury \& Lacombe, 2003; Loermans \& Fink, 2005).

In this paper, the methodological option assumed was to revisit some classic texts on competences, seeking to capture how those authors' implicitly or explicitly considered the overlap between this concept and organizational culture.

Zarifian (2001) offers an interesting reflection, incorporating the notion of culture with the development of competence by individuals. In order to develop their competence, people need to acknowledge the company's shared values, given that they only make sense within this context. According to the author, values cannot be imposed top-down, but should emerge from the group itself; they may then, at a later stage, become formalized. Although Zarifian recognizes that there are significant differences in terms of perceptions between the different levels of the company, given social discrepancies and different interests, Zarifian believes that in a strictly professional environment, culture may be shared, thus establishing a common language about what would be a competent practice in a specific professional scenario.

For example, showing how culture and different types of competences interact, in a study about salespeople and sales representatives, showed how culture, at its different levels - national, organizational and individual - influenced their negotiation styles and their performance.

Another author from the French school, Le Boterf, points out culture is as an important factor regarding the development of individual skills and their transformation into collective competence.

Culture as part of the organization's context largely defines what a competent employee is. "The updating of knowledge in a particular context (underscored by work relations, corporate culture, contingencies, time limitations related to resources, etc.) reveals the 'transformation' into competence. This occurs through action. It does not precede action" (Le Boterf, 1998, p. 49).

Moreover, competence is only competence when it makes sense within a particular professional context; in other words, something that has specific meaning for that culture: "The professional mobilizes his/her competence because of a project that is meaningful to him, a project to which he ascribes meanings" (Le Boterf, 1995, p. 155). 
The author further states that transfer of individual competence to collective competence also occurs through meanings. A way to find out whether collective competences have been assimilated is when a team learns how to prepare shared meanings.

Shared meanings are comprised of rules, collective values, priorities, interpretation schemes, action themes and common reference systems. They favor convergence of individual initiatives, mutual predictability of behavior and the pursuit of agreements (Le Boterf, 1995, p. 235).

Using the same rationale, McAuley (2004) present culture as the backstage for organizational dynamics, which determines what it means to be competent or not within a specific company. Thus, depending on the culture of the company, there would be better or worse conditions for developing a specific skill.

Prahalad and Hamel (1990) deal with the subject of culture indirectly when they discuss the process of unlearning required to develop a new organizational competence. The authors, in their proposal to develop the competences of an organization for its future success, regard culture as the company's genetic code, conducting its management body to act and think in a specific pattern.

What do we mean by a company's DNA? Every manager has in mind a number of tendencies, premises and assumptions about the structure of the relevant sector, about how to earn money in the specific sector, about who the competitors are (or are not), about what clients want and don't want, about which technologies are viable and which are not, and so on and so forth. This DNA also encompasses creeds, values and norms regarding the best way to motivate people, the ideal balance between internal cooperation and competition, the relative classification of the interests of shareholders, clients and employees, and the behaviors that should or should not be encouraged. These beliefs, at least in part, are the product of a specific environment. When this environment changes quickly and radically, these beliefs may become a threat to the company's own survival (Prahalad \& Hamel, 1990, pp. 55-56).

The authors point out some of the case studies in which companies achieved success because of a specific way in which they did things, but warned that this would not necessarily be a way that will guarantee future success. Thus, in the case of Prahalad and Hamel, the cultural approach has negative connotations: culture ties the company down to the past and must undergo transformations to enable development of competences for the future.

When discussing the relationship between organizational culture and sustained superior financial performance, Barney (1986) mentions that in order for a firm's culture to provide sustained competition advantages, three conditions must be met: the culture must be valuable (it must enable a firm to do things and behave in ways that lead to high sales, low costs, high margins), secondly, it must be rare, and thirdly it must be imperfectly imitable.

One very interesting case that is worth mentioning is Lincoln Electric, which despite intense domestic and foreign competition has managed to sustain, for over more than 100 years, its status as the world's leader in wedding technology. However, Maciariello (2000), analyzing Lincoln's culture and systems abroad, discussed the success and failures. According to this author, the ability of Lincoln to transfer its culture and management systems to its acquisitions has been very complex. In the case of greenfield operations in Canada, Australia and France, Lincoln was able to transfer part of its culture and management systems; even in Mexico, where they formed one company from the merger of three Mexican companies, the operation was successful. In other countries like Germany and Brazil, the Lincoln company for several reasons and preferred to retreat and not change the culture.

Therefore, organizational culture express a set of values that have been built over the course of the company's history, having been developed as part of its process of internal and external adaptation. Culture has deep roots and, in a way, it represents an organization's DNA. On the other hand organizational competences are the result of the company's coordination and mobilization of its resources, with the purpose of responding to the strategies established by the organization. Like culture, they arise and develop over time; however, their roots are not as deep. 
Is it possible to develop new competences and acquire resources that generate new competences without these processes implying deeper genetic changes in that DNA? Does organizational culture enhance or jeopardize the development of new competences? The analysis of two Brazilian companies will provide empirical evidence to advance in the discussion.

\section{THE CASE STUDY}

In order to discuss the questions mentioned above, two case studies of Brazilian companies were prepared. Those companies have been chosen because in the last decade they have been involved in internationalization processes that have challenged their core values and culture.

As suggested by Eisenhardt (1989), these case studies used a combination of the following data collection methods: document analysis, interviews and observation. Therefore, primary and secondary sources were consulted, such as the company's official documents, articles and publications about the company, interviews with directors, managers and company executives, and observation during several visits to the companies.

\section{Embraco}

Embraco, Empresa Brasileira de Compressores S.A., is a worldwide leader in hermetic compressors. Thirty-four years after it was first established, Embraco currently employs a staff of 10,238, has a $25 \%$ global market share, exports to several countries and has plants in Brazil, Italy, Slovakia and China, as well as offices in the United States and Mexico. Together, the plants have an annual capacity of over 26 million compressors.

Embraco was established in 1971, in the city of Joinville in Santa Catarina State, the joint undertaking of three refrigerator manufacturers: Consul, Springer and Prosdócimo. The plant went onstream in 1975. In 1982, Embraco entered into an agreement with the Federal University of Santa Catarina to create its own technology. The following year, the R\&D area was structured. Five years later, the first compressor entirely based on Embraco [EM] technology was launched.

In 1992, it began producing compressors with gases other than CFC and achieved ISO 9001 certification. In 1994, Embraco was elected company of the year by Exame magazine. In 1996, on its $25^{\text {th }}$ anniversary, it reached the milestone of 100 million compressors manufactured in Brazil, and received ISO 9001 certification in China. In 2004, Embraco sales grew 5.9\% and its revenues were $5.7 \%$ higher than in the previous year. Its main clients are Whirlpool and Electrolux. Other clients that are worth mentioning are Bosch, GE and LG.

Embraco headquarters and most of the plants are located in Brazil, in the south of the country; it has affiliated manufacturing units in China, Italy and Slovakia as well as offices in the United States and México.

Embraco's organizational culture is strongly influenced by regional traits and intensely influenced by the Germanic culture of the immigrants established in the south of Brazil (Joinville) in the $19^{\text {th }}$ century, valuing technical skills mainly. The company's declared values (commitment, excellence, innovation, integrity and respect) are present in the discourse of its managers, who believe that they are the key factors to the company's success and a source of pride. The company's heroes are connected with the values of respect, commitment, perfectionism and also pro-activity. The profile of staff and the executive board is highly homogeneous, consisting predominantly of men aged 40 to 50 , with an engineering background, who have been with the company for many years. They themselves recognize this homogeneity and wonder about their capability for coping with diversity. 
Throughout its 35-year history, Embraco has built a record of good results based on technical and technological competences as well as on logistics and operations management. Its values of excellence and innovation further strengthen these competences.

Embraco is a typical success case, mentioned by Prahalad and Hamel, given that success corroborates values and practices from the past and limits the creativity and flexibility required for the future. On the one hand, a stream of positive results creates a strong identity, internal cohesion and pride among employees. The Embraco style is fairly well established in the company and reinforced by management and an executive board that have been with the company for over ten years, which corroborates and deepens the cultural roots that keep the company strong and competitive.

By using Schein's categories, their basic assumptions can be expressed from their shared values and visible artifacts. In Embraco's case, values such as respect, dignity, commitment and perfectionism are examples entwined with the company's line of discourse, its physical layout and the way the organization thinks.

Schein also states that these assumptions are taken for granted, i.e., that they are so built in that they are neither conscious nor questionable. In Embraco's case, homogeneity and low turnover of management and senior management reinforce this idea.

However, Embraco seems to be uncomfortable with its homogeneity and assumes the need to reassess its values. One of the manifestations of this is that the process of review and reorganization of its management model is under way and is based on the contrast between new requirements and what has been learned over the company's history. Thus, Embraco expects to identify what has to change and what should be maintained in order to guarantee continuing good results in the future. Some of the organization's cultural traits (the homogeneous profile of management and of the executive board, a very masculine style and an exaggerated focus on the technical area) are being reassessed to help build a more flexible Embraco, better able to compete in a global market. The company is investing in the creation of a more flexible and favorable environment for this unlearning and learning process, while encouraging an internal feedback system, hiring new employees and offering several behavioral training courses for management, among other actions. In international operations, authoritarian Brazilian cultural traits, which are also reflected in the company's culture, came into conflict with the culture of operations in other countries. In Italy, for example, a less authoritarian and individualistic country, the introduction of management styles that harmonized technological competences with operational efficiency encountered strong resistance. The Italian employees expressed opinions such as "Who are those Brazilians, guys trying to bring us new ways of doing things?". Learning about and managing the Italian operation and negotiating with labor unions forced the company to rethink many of its behavior patterns.

In the case of China, the greatest challenge was to introduce technical and operational competence into a technologically backward plant with problems of product quality. For example, all the interviewees mentioned the dirt that had accumulated for years on the factory floor, which had required educational and disciplinary measures on the part of the Brazilian managers. The adjustments needed to deal with such questions related to a joint venture in a country that is so culturally different from Brazil was a learning experience for the Brazilian head office.

Other challenges had to be faced in Slovakia, a country that, until very recently, had been subject to an authoritarian communist regime. The company was unable to find qualified personnel for positions of leadership and with the technical competence that had always characterized its operations. The development of leaders who can take initiatives was also a challenge to Embracos's managers. They were used to a hierarchical culture; nevertheless they expected their leaders to take initiatives.

The progress of this process should affect the very underpinnings of the company and divert the course of its culture from its traditional path. 


\section{Votorantim Cimentos}

The Votorantim Group, which controls Votorantim Cimentos, was established in Brazil in 1918 and is one of the biggest Brazilian economic groups with businesses in cement, cellulose, paper, aluminum, zinc, nickel, long steel bars, polypropylene films, chemical specialties, orange juice and also financial, biotechnology and IT.

Votorantim Cimentos was established in 1936, with the Santa Helena plant located in the state of São Paulo, Brazil. Nowadays, it is a holding group, with plants in Brazil and abroad producing cement, whitewash, mortar and concrete. The company's principles are: health and occupational safety as priorities; motivated and committed competent people; harmony with the environment and commitment with quality of life; client satisfaction by highly trustable solutions with efficiency and rationality; improvement and synergy in processes, optimization performance of installations and equipment; intelligent low costs.

Votorantim is $100 \%$ Brazilian and had concentrated its activities in the domestic market. After the economic instabilities in Asia in 1999, the international groups turned their attention to Latin America, including Brazil (sixth in the world and half of South American demand). Thus, Lafarge, for example, bought Cia. Materiais Sulfurosos Matsulfur and acquired shares in the Cia de Cimento Portland Maringá and in the Cimento Tupi. The Swiss Holderbank has acquired Cimento Paraíso. The Portuguese Cimpor acquired Serrana/Cimbargé, Cisafra and plants from Brennand Group.

Under the threat of those international groups to the domestic market, Votorantim Cimentos started reviewing its locally focused strategy. By attempting to expand to other close markets (Latin America), the company found itself already encircled by its competitors in locations such as Venezuela, Colombia and Argentina. Holderbank, for example, paid a high price for the control of Juan Minetti, a cement company with an $18 \%$ share of the Argentinean market to avoid Votorantim acquiring it. Therefore, internationalization had become to keeping Votorantim's domestic leadership, diversify its cash flow and, principally, to defending itself from the intense wave of acquisitions led by the most important global players.

Its international activity started in 2001, by acquiring St. Marys, a Canadian company with plants in Ontario (39 for mortar and 2 for cement), in addition to nine distribution terminals in the Great Lakes area of the United States. In 2003, it acquired 50\% of Suwannee American Cement, a plant which had recently been built in the United States. In 2004, it acquired S\&W Materials Inc. in Jacksonville, one of the biggest concrete companies in Florida, and in 2005, two additional plants in Illinois and Michigan. Votoratim became one of the 10 biggest cement companies worldwide and in Brazil is the leader in cement and concrete (Engemix) The company is investing simultaneously in domestic expansion by building new plants, and has a goal of duplicating its international production in the next three years.

Like its main competitors, the company invests continually in the development of products with higher added value, in differentiated services and solutions for its clients and in the development of its employees. Fourteen of its units have already been certified in the highest level of the international health, security and environmental system.

By acquiring new factories, the greatest challenge was to transfer its culture of operational excellence and the low cost operations that embrace various tools (TPM, Six Sigma, Project Management, etc) that have been named as the Votorantim Cimentos Production System. On the other hand, knowledge in logistics (river transportation) and product (in Brazil a mixture is made with residues and sold basically in sacks while in the United States the product is pure, type one and it is sold in bulk) have been learned with the subsidiary, because there were significant differences from the domestic market. Therefore, since the acquisition, St Marys for example, has shown increasing regularity in production and sales, a $25 \%$ reduction of costs in the first year and working capital. 


\begin{abstract}
Another great challenge faced by Votorantim in the internationalization process is the cultural diversity between Brazil and Canada and between Brazil and the United States. Considerable differences can be seen in terms of distance from power, because Brazil is a more authoritarian and less individualistic country than the United States or Canada. These traits also appear in the culture of Brazilian companies. Votorantim, for example, has a very hierarchical culture with top-down, paternalistic-style management. At Saint Marys, Canadians experienced a more egalitarian and individualistic culture that gives great importance to the quality of life. One frequent complaint of expatriate Brazilian managers is that the Canadians strictly adhered to the established working schedules, thus guaranteeing their leisure time.
\end{abstract}

The introduction of new skills related to operational excellence and low operational costs was hampered by culture shock. Efforts had to be made to convince the Canadians through training programs and visits to units in Brazil.

In addition, the difficulties found at the beginning of the company's internationalization process led the managers involved to question the company's cultural patterns.

This is also particularly true in terms of the managers' mind set. and the need to develop a program for expatriation. On the Canadian side, there was resistance to accepting the viability of the project and the quality of Brazilian products. In order to convince the Canadian managers, more than 200 managers were invited to visit Votorantim's plants in Brazil. Other problems in people management were related to negotiation with unions, remuneration system and investments in people training to operate with the new methods.

From this process, Votorantim has began to position itself as a global player, challenging the most important international competitors by applying an operational excellence strategy based on technical and operational competences.

These are companies from a country known for great distance from power and with a more hierarchical and paternalistic culture. However, they are also flexible and able to deal with typical Brazilian shortcuts and impromptu solutions.

\title{
COMPARING THE TWO CASES
}

Even though some differences appear from the case studies, especially in terms of the distinctive characteristics of the industries where the two firms operate (manufacturing versus extractive), Embraco and Votorantim are examples of companies that have developed strong cultures with a set of values related to human resources management (commitment, long term employment, investments in training and development) and technical and technological competences.

On their processes of internationalization, they had a need to access markets and resources and subsequently to reduce production and transaction costs by coordinating their new activities In order to do so, they had to evaluate their "core competences" in terms of technical and managerial capabilities.

Does the prevailing culture of these two organizations enhance or jeopardize those internationalization process?

From the information gathered in the field, it is possible to state that Embraco had a proactive view on that process, probably associated to its Germanic roots. On the other hand, Votorantim presented a more reactive type of behaviour. Notwithstanding, in both cases the existing culture brought some difficulties for the development of competences: both were traditional Brazilian firms, strongly committed to the Brazilian market and the country development project; their management staff had low exposure to a global environment, with a limited global mind set. 
Therefore, at the first stage both companies had to learn to deal with cultural obstacles.

However, as Prahalad and Hamel (1990, p. 79) point out, companies should be concerned about future success, preparing and rebuilding themselves for this, rather than functioning as a copy of the past. The authors believe that

lessons deeply rooted in the past, passed on from one generation of managers to the next, create two dangers for any company. First, individuals may forget, over time, why they believe in what they believe. Second, managers may even believe that it is not worth knowing what they do not know.

Both companies are learning how to cope with these challenges. The next stages will imply internalizing what they have learnt on their overseas operations.

\section{FINAL COMMENTS}

The objective of this paper was to discuss two concepts: culture and competence, questioning the relationship between them: does the organization's culture enhance or jeopardize the development of new competences? Are they topics that overlap, complement or contradict each other?

The option of reassessing classic authors in the study of these two subjects provided interesting clues for their understanding.

If we take competence at the individual and collective level, in the approaches proposed by Zarifian and Le Boterf, we can see that culture plays an essential role. Given that the idea of context is an essential aspect for these authors and that context, by definition, is an interpretation of the reality experienced by a group (Weick, 1973), culture will always be the main reference for determining what is or is not competent behavior for the group. In other words, in a culture in which engineering values are predominant and in which technically perfect products are the ones that have value, competences related to business, marketing and brand and image management may play a secondary role. If the factors of adaptation to a business environment begin to require these competences, acquiring them or developing them will necessarily imply a review of the predominant culture.

When we analyze competences at the organizational level, using Prahalad and Hamel and Mills as references, the analysis becomes somewhat more complex. This is the case because culture - as stated by Linda Smirch - can be seen as something that the company is, but it can equally be something that the company has, depending on the chosen approach. But culture is also something that the group uses in its internal and external relations, with a view to its survival (Schein, 1985) and preparation for the future, i.e., it is also a resource that can be mobilized - a highly particular resource, more important than others, given that its mobilization is actually the mobilization of the group's reason for being, but nevertheless a resource. Values and beliefs are handled, internalized, discarded, valued and used in different ways by the staff and employees, participants in organizational life.

Similarly, competences are not static, but variable (Mills), as they only exist with the dynamics of resource coordination in a given established context (Le Boterf). A set of resources, on the other hand, is submitted to constant processes of development acquisition, disposal, maintenance and valuation.

If culture influences the company's way of being and of doing things, one can conclude that it also influences purchasing decisions or the development of resources and their mobilization to produce results.

Therefore, cultural practices can guide and uphold the development of certain competences to the detriment of others, depending on their configuration. Prahalad and Hamel's recommendation to diversify an organization's staff as well as to review values and beliefs through an unlearning process 
capable of providing a broader view of reality and the development of new competences that can make future success viable makes sense.

Culture and competency reflect a delicate relationship that needs to be researched and managed with care within organizations.

\section{REFERENCES}

Alcadepani, R., \& Crubellate, J. (2003). Cultura organizacional generalizações improváveis e conceituações empresariais. Revista de Administração de Empresas, 3(2), 64-77.

Almeida, A. (2007). A cabeça do brasileiro. Rio de Janeiro: Editora Record.

Barney, J (1986). Organizational culture: can it be a source of sustained competitive advantage?. The Academy of Management Review, 11(3), 656 - 665.

Bion, W. R. (1975). Experiências com grupos: os fundamentos da psicoterapia de grupo (2a ed.). Rio de Janeiro, São Paulo: Imago/Edusp.

Borges, R. C. O. Borges, V. B., \& Borges, F. C. M (2008, junho). O panorama de estudos acadêmicos em cultura organizacional no século XXI: um levantamento nos anais dos ENANPADS. Anais do Encontro de Estudos Organizacionais, Belo Horizonte, MG, Brasil, 5.

Caldas, M. (2006). Conceptualizing brazilian multiple and fluid cultural profiles. Management Research, 4, 187-198.

Dias, G. B., Becker G. V., Dutra, J. S., Ruas, R. (2008). Competências: conceitos, métodos e experiências. São Paulo: Atlas.

Eisenhardt, K. M. (1989). Building theories from case study research. The Academy of Management Review, 14(4), 532-550.

Fleury, A. C. C., \& Fleury, M. T. L. (2004). Alinhando estratégias e competências. Revista de Administração de Empresas, 44(1), 44-57.

Fleury, M. T. L., \& Fischer, R.M. (Orgs.). (1989). Cultura e poder nas organizações. São Paulo: Atlas.

Fleury, M. T. L., \& Lacombe, B. (2003). Managing competencies and human resources management. Anais do Ibero American Academy of Management, São Paulo, SP, Brasil, 24.

Fleury, M. T. L., Shinyashiki, G. T., \& Stevanato, L. A. (1997). Entre a antropologia e a psicanálise: dilemas metodológicos dos estudos sobre cultura organizacional. Revista de Administração da USP, 32(1), 23-37.

Freitas, M. E. (1991). Cultura organizacional: formação tipologias e impactos. São Paulo: Makron, McGraw-Hill.

Hilal, A. V. G. de (2006). Brazilian national culture, organizational culture and cultural agreement: findings from a multinational company. International Journal of Cross Cultural Management, 6(2), 139-167.

Hofstede, G. (1991). Cultura e organizações. Lisboa: Silabo.

Le Boterf, G. (1995). De la competence. Paris: Les Editions d’Organisation. 
Le Boterf, G. (1998). De la compétence à la navigation professionnelle (2ième èd.). Paris: Les Editions D'Organization.

Loermans, J., \& Fink, D. (2005). How organisations evaluate their knowledge management projects: a meta study of the period 1992-200. Knowledge Management Research \& Practice, 3(3), 125135 .

Maciariello, J. (2000). Lasting value - lessons from a century of agility at Lincoln electric. New York: John Wiley \& Sons.

McAuley, J. (2004). Exploring issues in culture and competence. Human Relations, 47(4), 417-430.

Mills, J. (2007). On the contract - what is next? [Working Paper], Cambridge, MA.

Mills, J., Platts, K., Bourne, M., Richards, H. (2002). Strategy and performance: competing through competences. Cambridge: Cambridge University Press,.

Peteraf, M. A., \& Barney, J. B. (2003). Unraveling the resource-based tangle. Managerial and Decision Economics, 24(4), 309-323.

Pettigrew A. (1979). On studying organizational cultures. Administrative Science Quaterly, 24(4), 580-581.

Prahalad, C. K., \& Hamel, G. (1990). The core competence of the corporation. Harvard Business Review, 68(3), 79-91.

Prestes Motta, F., \& Caldas, M. (1997). Cultura organizacional e cultura brasileira. São Paulo: Atlas.

Reichers, A. E, \& Scneider, B. (1990). Organizational climate and culture. San Francisco: JosseyBass.

Rodrigues, S. (2006). The political dynamics of organizational culture in an instituonalized environment organizational studies [Working Paper $\mathrm{n}^{\circ}$ 27), University of Birmingham, Birmingham, UK.

Schein, E. H. (1985). Organizational culture and leadership. São Francisco: Jossey Boss.

Schein, E. H. (2001). Guia de sobrevivência da cultura corporativa. Rio de Janeiro: José Olympio,

Smirch, L. (1983). Concepts of culture and organizational analysis. Administration Science Quaterly, 28(3), 339-358.

Tanure, B. (2003). Gestão a brasileira: uma comparação entre América Latina, Estados Unidos, Europa e Ásia. São Paulo: Atlas.

Teece, D. J., Pisano, G., \& Shuen, A. (1997). Dynamic capabilities and strategic management. Strategic Management Journal, 18(7), 509-533.

Vasconcellos, F. C., \& Cyrino, A. B. (2002). Vantagem competitive os modelos teoricos atuais e a convergência entre estratégia e teoria organizacional. Revista de Administração de Empresas, 40(4), 20-37.

Weick, K. E. (1973). Psicologia social da organização. São Paulo: Edgard Blücher,

Zarifian, P. (2001). Objetivo competência: por uma nova lógica. São Paulo: Atlas. 